\title{
EFFECT ON THE COMPRESSIVE STRENGTH OF MORTARS USING GROUND GRANULATED BLAST FURNACE SLAG AS A PARTIAL REPLACEMENT OF CEMENT
}

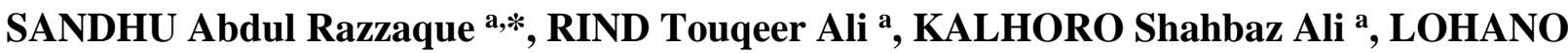 \\ Rahol ${ }^{\text {b }}$, LAGHARI Faizan Hyder ${ }^{\text {a }}$ \\ ${ }^{a}$ Mehran University of Engineering and Technology, Department of Civil Engineering, Shaheed Zulfiqar Ali Bhutto Campus, \\ Khairpur Mirs', Sindh, Pakistan, e-mail:* abdulrazzaque@muetkhp.edu.pk \\ ${ }^{\mathrm{b}}$ NED University of Engineering and Technology, Department of Civil Engineering, Karachi, Sindh, Pakistan
}

Received: 21.06.2019 / Accepted: 06.09.2019/ Revised: 10.10.2019 / Available online: 10.12.2019

DOI: 10.2478/jaes-2019-0025

KEY WORDS: Ground granulated blast furnace slag (GGBFS); Sustainable Concrete; Partial Cement Replacement.

\begin{abstract}
:
Mortar is widely used in the construction industry for different purposes. Its compressive strength is the main parameter which is brought under focus. Compressive strength of mortars depends upon many factors such as water-cement ratio, fine aggregates size, and different curing conditions. This experimental study was undertaken to investigate the effect of GGBFS on compressive strength of mortars under different curing regimes using GGBFS as a partial replacement of cement. A total of 60 cubes of standard size of $2 \mathrm{x}$ $2 \times 2$ inches were casted in laboratory, out of which 12 cubes each were prepared with $0 \%, 5 \%, 10 \%, 15 \%$ and $20 \%$ GGBFS replacement for cement. Cubes were cured for 3, 7, 14 and 28 days. Bases on obtained results it is observed that the maximum compressive strength was achieved by sample with 5\% GGBFS, although 10\% GGBFS samples achieved higher compressive strength than the control sample with 0\% GGBFS. Further replacement beyond this value causes reduction in strength.
\end{abstract}

\section{INTRODUCTION}

Today is the era of innovations in construction technology. The development of advanced materials and applications of modern techniques have been the active area of research. There is an everincreasing urge of infrastructures. These infrastructures are considered to be the backbone of country's economy (Khitab et al., 2013), as construction industry plays pivotal role in socioeconomic uplift of a country (Sohu et al., 2018; Jhatial et al., 2018a). Concrete has become one of the most preferred building materials in the world for civil engineering projects ranging from residential houses, tall structures, bridges and dams (Sandhu et al., 2019). This preference is mainly due to ease of moulding, durability, serviceability and strength (Aprianti, 2017). The production of concrete's main ingredient, cement, has raised environmental concerns, as according to recent reports, it is estimated that the cement industry is responsible for release of approximately $10 \%$ of the total global carbon dioxide $\left(\mathrm{CO}_{2}\right)$ gas (Mohamad et al. 2019a; Suhendro, 2014). Negative impact on the environment associated with the production of cement possesses tremendous pressure on the construction industry to reduce the dependency of cement as the main binder in the manufacturing of concrete. Therefore, researches have been conducted to find a liable alternative for cement replacement.
The generation of various waste materials has been on the raise due to the increase in urbanization (Abdel-Shafy et al. 2018). These solid wastes are typically thrown away or disposed-off into landfills without proper treatment, and ultimately cause health risks to the surrounding residents along with adversely affecting the environment (Jhatial et al., 2018b). Awareness has been growing for the reusing / recycling such waste materials in order to benefit from its various properties. One potential method for recycling / reusing the waste materials is to utilize them as supplementary cementitious materials (SCMs). Most of the waste materials, due to their chemical composition, contain significant amounts of Silica Oxide $\left(\mathrm{SiO}_{2}\right)$ or Calcium Oxide $(\mathrm{CaO})$.

Ground granulated blast furnace slag (GGBFS) is a by-product of iron and steel-making (Saha \& Rajasekaran, 2017; Patil et al., 2013). Its chemical composition may vary significantly depending upon the composition of the raw materials that are used in the production of iron. The utilization of GGBFS as partial cement could significantly reduce the $\mathrm{CO}_{2}$ emissions, reduce the amount of GGBFS waste, and decrease the construction industry's dependency on cement as sole binder. The durability aspects of reinforced concrete structures are enhanced with the inclusion of GGBFS (Suresh \& Nagaraju, 2015). Furthermore, concrete containing GGBFS has the ability

\footnotetext{
* Corresponding author. Abdul Razzaque SANDHU, e-mail: abdulrazzaque@ muetkhp.edu.pk
} 
to resist environmental actions such as chloride penetration, sulphate attack and alkali-silica reactive expansion, thus allowing the concrete to have a longer corrosion-free service life (Mo et al., 2015).

This experimental research has been conducted to study the effect of GGBFS on the compressive strength of mortar, and to find out the optimum replacement percentage of cement with GGBFS. Research has been ongoing to develop sustainable concrete by addition of various SCMs and admixtures in the concrete (Mangi et al., 2019; Rahman et al., 2019; Ashish 2019; Gettu et al., 2019; Jhatial et al., 2019; Juenger et al., 2019; Mohamad et al., 2019b; Phul et al., 2019; Martirena \& Monzó, 2018, Kamaruddin et al., 2018). Cement mortar is also as a type of concrete, which is being used in many applications such as finish and repair, concrete cover to normal RCC structures from environmental effects, manufacture of ferrocement elements and protection layer to the porous construction material such as light weight concrete elements or brick masonry walls. Pakistan is a developing country having major part as rural areas (Baig \& Khan, 2006). The most of buildings constructed in these areas are load bearing consisting brick masonry (Shah et al., 2019). Also, the partition walls in the framed RC structures are made with the bricks. These brick masonry walls are then plastered with the cement mortar. The performance of masonry work is dubious due to many reasons such as source and quality of raw material (clay), moulding and compression method, process of manufacture, temperature and duration of firing etc. The durability and the service life of these masonry elements are adversely affected by the hazardous environmental conditions if not plastered with the appropriate mortar. Thus, the role of the plastering mortar becomes very important in case of overall performance of brick masonry structural elements. Therefore, to improve the performance of mortar in different aspects has also ever been remained area of researchers. In this regard a lot of work has been reported in the literature. During the past decades, a trend has been seen in the use of SCMs in the manufacturing of concrete, whether natural waste or by-products (Harbulakova et al., 2015). This technique not only improves the performance of the concrete but tend to the solution of the dumping of waste material which needs a large space and causing environmental pollution too. GGBFS is one of the cementitious materials which are widely used to improve the strength and durability of concrete. This led to the idea to undertake an experimental study to investigate the effect of GGBFS on compressive strength properties of mortar by using it as a partial replacement of cement.

\section{RESEARCH METHODLOGY}

In order to investigate the effect of GGBFS as a partial replacement with cement at different percentages from 5\% to $20 \%$ with an increment of $5 \%$ on strength of mortar, the details of material selection, casting of specimens, instrumentation and testing are given below.

\subsection{Materials:}

Ordinary Portland Cement (OPC) of Type-1 complying the specifications of ASTM C150 / C150M - 19a and BS EN 1971:2011. Bolhari sand locally available, passed through \#16 sieve is used. The sand was washed to remove any sticky particles followed by its drying up to SSD. During this study also, drinkable water was used to produce the mortars without band with GGBFS. During this study the GGBFS was purchased from the steel mill Karachi. Dosage of GGBFS which was used as a partial replacement of the cement is 5\%,10\%,15\% and 20\%. In addition, a normal mortar without GGBFS was also casted and tested for comparison of the results. Thus, in total 5 batches of the specimens were casted and tested during this study. The physical properties of cement and aggregates are given in Table 1 while the details of the designation and specification of the batches are given in Table 2. Throughout the study mortar ratio of 1: 2.75 (Cement: Sand) was considered with fixed water cement ratio of 0.5 .

Table 1. Properties of cement and sand

\begin{tabular}{|l|l|}
\hline Properties & Value \\
\hline Cement & 3.12 \\
\hline Specific Gravity & 45 minutes \\
\hline Initial Setting Time & 360 minutes \\
\hline Final Setting Time & \\
\hline \multicolumn{2}{|l|}{} \\
\hline Fine Aggregates (Sand) & 2.62 \\
\hline Specific Gravity & $2.2 \%$ \\
\hline Water Absorption & 3.25 \\
\hline Fineness Modulus
\end{tabular}

Table 2. Mix Proportion of Mortars

\begin{tabular}{|l|l|l|}
\hline Mix Proportion & Cement \% & GGBFS \% \\
\hline M0 & $100 \%$ & $0 \%$ \\
\hline M5 & $95 \%$ & $5 \%$ \\
\hline M10 & $90 \%$ & $10 \%$ \\
\hline M15 & $85 \%$ & $15 \%$ \\
\hline M20 & $80 \%$ & $20 \%$ \\
\hline
\end{tabular}

\subsection{Experimental Work}

All the materials, including water, were weighed prior to their mixing. Initially sand, coarse aggregates and binder (OPC and GGBFS) were mixed thoroughly for about 3-5 minutes to ensure uniform dispersion of GGBFS in the mix. The water was added gradually into the concrete mixer such that water can be distributed uniformly on the dry mix and mixing continued for about 3 minutes in order to achieve the uniform mix. The specific specimens of standard size were cast. After 24 hours, the specimens were demoulded and cured for 3, 7, 14 and 28 days. The specific specimens were tested in universal testing machine (UTM) for compressive strength in accordance to the standard procedures of testing.

\section{RESULTS AND DISCUSION}

\subsection{Compressive Strength Behaviour}

The average compressive strength of mortar incorporating GGBFS was recorded at different curing periods and in accordance to the guidelines of ASTM C39. The results are tabulated in Table 3 and illustrated in Figure 1. 
Table 3. Average Compressive Strength of Mortar over Different Curing Days

\begin{tabular}{|c|c|c|c|}
\hline $\begin{array}{c}\text { Curing } \\
\text { Days }\end{array}$ & Mix & $\begin{array}{c}\text { Average } \\
\text { Compressive } \\
\text { Strength (MPa) }\end{array}$ & $\begin{array}{c}\text { Difference in strength } \\
\text { with respect to M0 } \\
\text { sample (\%) }\end{array}$ \\
\hline \multirow{4}{*}{ 3 Days } & M0 & 16.89 & --- \\
\cline { 2 - 4 } & M5 & 17.71 & $+4.85 \%$ \\
\cline { 2 - 4 } & M10 & 19.75 & $+16.93 \%$ \\
\cline { 2 - 4 } & M15 & 18.65 & $+10.42 \%$ \\
\cline { 2 - 4 } & M20 & 15.51 & $-8.17 \%$ \\
\hline \multirow{4}{*}{ 7 Days } & M0 & 19.5 & --- \\
\cline { 2 - 4 } & M5 & 23.14 & $+18.67 \%$ \\
\cline { 2 - 4 } & M10 & 22.90 & $+17.44 \%$ \\
\cline { 2 - 4 } & M15 & 21.65 & $+11.03 \%$ \\
\cline { 2 - 4 } & M20 & 16.01 & $-17.90 \%$ \\
\hline \multirow{4}{*}{ 14 Days } & M0 & 20.64 & --- \\
\cline { 2 - 4 } & M5 & 23.34 & $+13.08 \%$ \\
\cline { 2 - 4 } & M10 & 23.07 & $+11.77 \%$ \\
\cline { 2 - 4 } & M15 & 21.12 & $+2.33 \%$ \\
\cline { 2 - 4 } & M20 & 18.05 & $-12.55 \%$ \\
\hline \multirow{4}{*}{ 28 Days } & M0 & 26.27 & --- \\
\cline { 2 - 4 } & M5 & 32.67 & $+24.36 \%$ \\
\cline { 2 - 4 } & M10 & 29.79 & $+11.82 \%$ \\
\cline { 2 - 4 } & M15 & 22.90 & $-12.83 \%$ \\
\cline { 2 - 4 } & M20 & 19.91 & $-24.21 \%$ \\
\hline
\end{tabular}

It can be observed from Table 3 and Figure 1 that up to $15 \%$ GGBFS showed increase in compressive strength at early stages. However, once the mortars start to harden, at 28 days curing, the $15 \%$ GGBFS stopped gaining strength and strength achieved was significantly less compared to the control sample. Interestingly though, the 5\% GGBFS showed impressive increase in compressive strength, $10 \%$ GGBFS showed some strength gain than control sample.

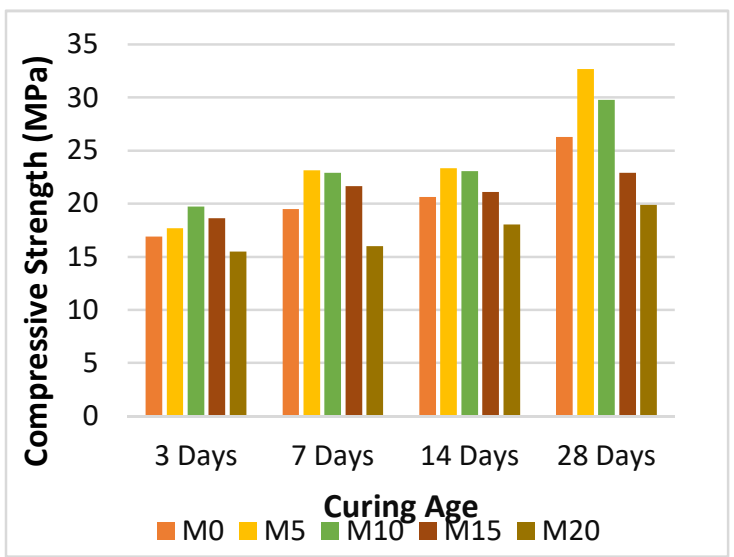

Figure 1. Influence of GGBFS on the strength of mortars

GGBFS significantly affects the compressive strength of mortar/concrete when it is added or used as partial replacement of cement. The aggregate in concrete behaves as inert filler but it causes the weak interfacial zone with cement paste. But, the addition of GGBFS improves the bond between the binder paste and sand leading to the development of denser mortar resulting in high strength of GGBFS mortars.

GGBFS is considered as essential constituent to produce high performance mortar/concrete. This increase in the strength was attributed to the stronger bond developed between the cementGGBFS paste and the sand. GGBFS also may be used with the addition of the superplasticizers which increases the workability of the fresh mix and reduce the water demand resulting in the higher strength of the hardened product (Ghrici et al., 2007; Chindaprasirt et al., 2005).

M15 and M20 samples achieved significantly lower strength compared to M0, this may be attributed to pozzolanic reaction being slow and requires $\mathrm{CaOH}$ to form pozzolanic reaction, since M15 and M20 have reduced cement content, there is less $\mathrm{CaOH}$ available at that time so resulting in less strength (Khan \& Ganesh, 2016).

\section{CONCLUSION}

The utilization of post-consumer wastes and by-products in concrete has become a necessity. A great potential exists to reduce the concrete industry's contributions to greenhouse gases through reductions in cement consumption. Due to concrete's large consumption and utilization of cement as its one-and-only binder, even small reductions of cement content in concrete could make a significant global impact. Therefore, this experimental work was undertaken to determine the effect of GGBFS as partial cement replacement on the compressive strength of concrete at different curing stages.

Based upon the results it can be concluded that GGBFS is a supplementary cementitious material, which has the potential to be considered as a partial binder and reduce the cement content. It was found that concrete samples containing 15\% GGBFS (M15) achieved high early strength compared to control samples (M0) but as the curing period increased, its compressive strength did not develop and as such on 28 days it lost approximately $13 \%$ strength compared to M0. However, concrete samples containing $5 \%$ (M5) achieved the maximum compressive strength at 28 days, approximately $24.36 \%$ higher than M0. Although M10 achieved higher strength than control sample with more cement replacement of $10 \%$. Since the aim of the study was to reduce the cement content in mortar, therefore, it is advisable that concrete incorporating $10 \%$ GGBFS as cement replacement be used, since mortar achieves no strength loss.

\section{References:}

Abdel-Shafy, H. I., \& Mansour, M. S. (2018). Solid waste issue: Sources, composition, disposal, recycling, and valorization. Egyptian journal of petroleum, 27(4), $1275-1290$.

Aprianti, E. (2017). A huge number of artificial waste material can be supplementary cementitious material (SCM) for concrete production-a review part II. Journal of cleaner production, 142, 4178 - 4194.

Ashish, D. K. (2019). Concrete made with waste marble powder and supplementary cementitious material for sustainable development. Journal of cleaner production, 211, 716 - 729.

ASTM C39 / C39M-18, Standard Test Method for Compressive Strength of Cylindrical Concrete Specimens, ASTM International, West Conshohocken, PA, 2018, www.astm.org.

ASTM C150 / C150M-19a, Standard Specification for Portland Cement, ASTM International, West Conshohocken, PA, 2019, www.astm.org.

Baig, M. B., \& Khan, N. (2006). Rural development in Pakistan: From vision to action. The Rural Citizen: Governance, Culture and Well-Being in the 21st Century. University of Plymouth, UK. 
BS EN 197-1:2011, Cement. Composition, specifications and conformity criteria for common cements, British Standard Institution.

Chindaprasirt, P., Jaturapitakkul, C., \& Sinsiri, T. (2005). Effect of fly ash fineness on compressive strength and pore size of blended cement paste. Cement and Concrete Composites, 27(4), 425 - 428.

Gettu, R., Patel, A., Rathi, V., Prakasan, S., Basavaraj, A. S., Palaniappan, S., \& Maity, S. (2019). Influence of supplementary cementitious materials on the sustainability parameters of cements and concretes in the Indian context. Materials and Structures, 52(1), 10.

Ghrici, M., Kenai, S., \& Said-Mansour, M. (2007). Mechanical properties and durability of mortar and concrete containing natural pozzolana and limestone blended cements. Cement and Concrete Composites, 29(7), 542 -549 .

Harbulakova, V. O., Purcz, P., Estokova, A., Luptakova, A., \& Repka, M. (2015). Using a Statistical Method for the Concrete Deterioration Assessment in Sulphate Environment. Chemical Engineering Transactions, 43, 2221 - 2226.

Jhatial, A. A., Sohu, S., Memon, M. J., Bhatti, N. K. \& Memon, D. (2019). Eggshell powder as partial cement replacement and its effect on the workability and compressive strength of concrete. International Journal of Advanced and Applied Sciences, 6(9), 71 - 75.

Jhatial, A. A., Sohu, S., Bhatti, N. K., Lakhiar, M. T., \& Oad, R. (2018a). Effect of steel fibres on the compressive and flexural strength of concrete. International Journal of Advanced and Applied Sciences, 5(10), 16 - 21.

Jhatial, A. A., Goh, W. I., Mohamad, N., Sohu, S., \& Lakhiar, M. T. (2018b). Utilization of Palm Oil Fuel Ash and Eggshell Powder as Partial Cement Replacement-A Review. Civil Engineering Journal, 4(8), 1977 1984.

Juenger, M. C., Snellings, R., \& Bernal, S. A. (2019). Supplementary cementitious materials: New sources, characterization, and performance insights. Cement and Concrete Research, 122, 257 - 273.

Kamaruddin, S., Goh, W. I., Jhatial, A. A., \& Lakhiar, M. T. (2018). Chemical and Fresh State Properties of Foamed Concrete Incorporating Palm Oil Fuel Ash and Eggshell Ash as Cement Replacement. International Journal of Engineering \& Technology, 7(4.30), 350 - 354.

Khan, R. A., \& Ganesh, A. (2016). The effect of coal bottom ash (CBA) on mechanical and durability characteristics of concrete. Journal of building materials and structures, 3(1), 31 - 42 .

Khitab, A., Arshad, M. T., Awan, F. M., \& Khan, I. (2013). Development of an acid resistant concrete: a review. International Journal of Sustainable Construction Engineering and Technology, 4(2), 33 - 38.

Martirena, F., \& Monzó, J. (2018). Vegetable ashes as supplementary cementitious materials. Cement and Concrete Research, 114, 57 - 64.

Mangi, S. A., Wan Ibrahim, M. H., Jamaluddin, N., Arshad M. F., Memon, S. A., Shahidan, S. (2019). Effects of Grinding Process on the Properties of the Coal Bottom Ash and Cement Paste. Journal of Engineering Technological Sciences, 51(1): 1 - 13 .

Mo, K. H., Alengaram, U. J., \& Jumaat, M. Z. (2015). Utilization of ground granulated blast furnace slag as partial cement replacement in lightweight oil palm shell concrete. Materials and structures, 48(8), 2545 $-2556$

Mohamad, N., Lakhiar, M. T., Samad, A. A. A., Mydin, M. A. O., Jhatial, A. A., Sofia, S. A., ... \& Ali, N. (2019a). Innovative and sustainable green concrete-A potential review on utilization of agricultural waste. In IOP Conference Series: Materials Science and Engineering (Vol. 601, No. 1, p. 012026). IOP Publishing.

Mohamad, N., Iman, M. A., Samad, A. A. A., Mydin, M. A. O., Jusoh, S., Sofia, A. \& Lee, B. (2019b). Flexure Behaviour of Foamed Concrete
Incorporating Banana Skin Powder and Palm Oil Fuel Ash Strengthened with Carbon Fibre Reinforced Plate. IOP Conference Series: Materials Science and Engineering (Vol. 601, No. 1, p. 012025). IOP Publishing.

Patil, Y. O., Patil, P. N., \& Kumar, D. A. (2013). GGBS as partial replacement of OPC in cement concrete-An experimental study. International Journal of Scientific Research, 2(11), 189 - 91

Phul, A. A., Memon, M. J., Shah, S. N. R., \& Sandhu, A. R. (2019). GGBS and fly ash effects on compressive strength by partial replacement of cement concrete. Civil Engineering Journal, 5(4), 913 - 921.

Rahman, A. F., Goh, W. I., \& Jhatial, A. A. (2019). Flexural Study of Reinforced Foamed Concrete Beam Containing Palm Oil Fuel Ash (POFA) and Eggshell Powder (ESP) as Partial Cement Replacement. International Journal of Sustainable Construction Engineering and Technology, 10(1), $93-100$.

Saha, S., \& Rajasekaran, C. (2017). Enhancement of the properties of fly ash based geopolymer paste by incorporating ground granulated blast furnace slag. Construction and Building Materials, 146, 615 - 620 .

Sandhu, A. R., Lakhiar, M. T., Jhatial, A. A., Karira, H., \& Jamali, Q. B. (2019). Effect of River Indus Sand and Recycled Concrete Aggregates as Fine and Coarse Replacement on Properties of Concrete. Engineering, Technology \& Applied Science Research, 9(1), 3831 - 3834.

Shah, T. M., Kumar, A., Shah, S. N. R., Jhatial, A. A., \& Janwery, M. H. (2019). Evaluation of the Mechanical Behavior of Local Brick Masonry in Pakistan. Engineering, Technology \& Applied Science Research, 9(3), $4298-4300$.

Sohu, S., Ullah, K., Jhatial, A. A., Jaffar, M., \& Lakhiar, M. T. (2018). Factors adversely affecting quality in highway projects of Pakistan. International Journal of Advanced and Applied Sciences, 5(10), $62-66$.

Suhendro, B. (2014). Toward green concrete for better sustainable environment. Procedia Engineering. 95: 305 - 320.

Suresh, D., \& Nagaraju, K. (2015). Ground granulated blast slag (GGBS) in concrete-a review. IOSR Journal of Mechanical and Civil Engineering, 12(4), $76-82$. 